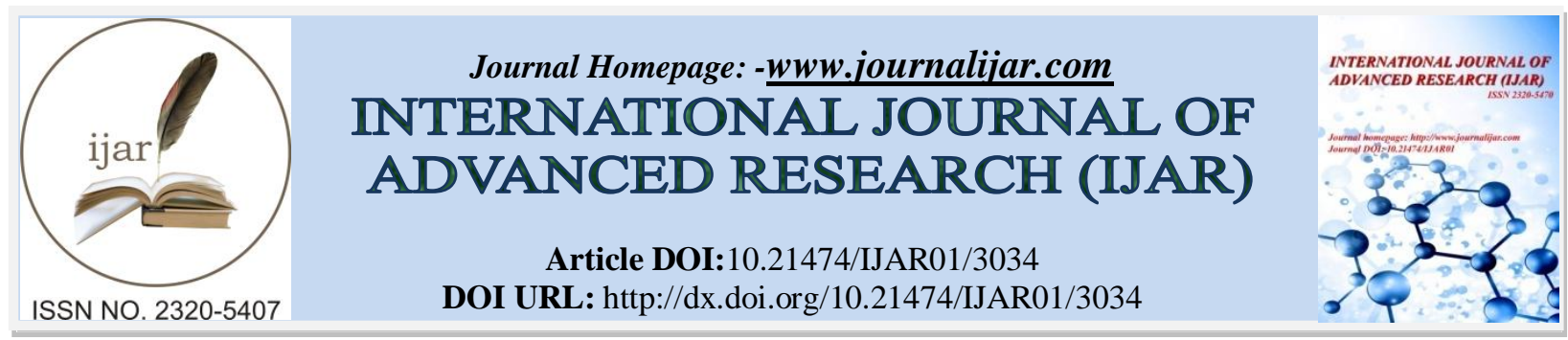

RESEARCH ARTICLE

\title{
OIL-ON-WATER MQL MACHINING OF NICKEL BASED SUPER ALLOY NIMONIC C.263
}

Sabahudin Ekinovic ${ }^{1}$, Halim Prcanovic ${ }^{2}$ and Edin Begovic ${ }^{1}$.

1. University of Zenica, Faculty of Mechanical Engineering,Fakultetska 1, 72000 Zenica, Bosnia \& Herzegovina.

2. University of Zenica, Metallurgical institute "Kemal Kapetanović"Travničkacesta 7, 72000 Zenica, Bosnia \& Herzegovina.

\section{Manuscript Info}

Manuscript History

Received: 30 November 2016

Final Accepted: 28 December 2016

Published: January 2017

Key words:-

Dry machining; Semi-dry machining; Metal working fluid; Nimonic C.263; Machinability; Cutting forces; Cutting temperature; Surface roughness

\begin{abstract}
Increasing demand for gas turbines (air and automobile industry) resulted in need for materials resistant at elevated work temperatures. Use of these materials increases the utilization factor since input temperatures are higher. For these applications high dynamic strength materials and materials with small elongation at elevated temperatures are needed. Furthermore, these materials should be resistant on corrosion of exhaust gases. High strength at elevated temperatures classifies them in the group of hard-to-machine materials. Since machining of super alloys generates great deal of heat, it must be dissipated using large quantity of metal working fluids (MWFs). Cost of metal working fluids is increasing as the number and extent of environmental regulations increase. To decrease the impact on environment new machining techniques are developed. These techniques use minimal quantities of metal working fluids in quantities from 10 to $50 \mathrm{ml} / \mathrm{h}$.Furthermore, there is no cost associated with treatment and disposal of MWFs, simply because there is nothing to dispose. It is well known that flood technique produces large quantity of waste which is classified as hazardous. This work deals with research of machinability of these super alloys using dry and semi-dry machining techniques, as environmental friendly techniques and as answer to the ever rising costs of production of machining operation with flooding of cutting zone.
\end{abstract}

Copy Right, IJAR, 2016,. All rights reserved.

\section{Introduction:-}

Increasing impact of machining process on environment resulted in increasing costs of production mostly because of the cost of MWFs regarding its disposal since they are classified as a hazardous waste. Misunderstanding of the role of metal working fluid in machining and wrong assumption that MWFs application is needed but not necessary element of the machining process lead towards inadequate use of the metalworking fluids. This inadequate use increases the impact on environment even more. Yet, positive applications of MWFs, concerning cutting forces, surface roughness, tool life and cutting temperatures, are reported every day, so this necessary part of machining process somehow must be reconciledwith environment protection. If MWFs are going to be used, impact on environment must be minimized, and now days this is obligatory requirement.

Corresponding Author:-Sabahudin Ekinovic.

Address:-University of Zenica, Faculty of Mechanical Engineering,Fakultetska 1, 72000 Zenica, Bosnia \& Herzegovina. 
Basic functions of MWFs in machining are: lubrication, cooling, chip transport and protection of work piece and machine tool against corrosion (if only oil as MWF is used [1]). Cooling, chip transport and corrosion protection are pretty much explainable mechanisms but lubrication mechanism is still poorly explained. Extensive research is done and no proof is found for penetration of MWF into chip-tool interface. If there is no penetration how could lubrication occur? Still, there are no valid scientific explanations on how metal forking fluids actually work. Given explanations [2] are not fully accepted because there are no experimental conformations to support given theoretical assumptions. Hence, this field is still wide open for research.

Some experiments [2] about efficiency of MQL technique against conventional machining operations (flood machining) offered very interesting and promising mechanism of the penetration of MWFs into the chip-tool interface based on Rebinder's effect. These explanations could lead towards explaining how MQL actually works. Performed experiments led to conclusion that MQL enhance embrittlement of the material being removed, hence lowering cutting forces in that way. Since MQL machining is inferior in comparison to flood machining especially to high pressure supply of MWFs, the size of the particles and the way they enter into the cutting zone got to play important role in MQL machining. Maybe, that's the reason why in some cases (when machining aluminum) MQL machining gives better results even than flood machining [3]. Furthermore, Thakur at al. (2009) proved that MQL could successfully be used to perform machining of super alloy Inconel 718 [4].

Dry and semi-dry machining are promising alternatives for conventional (flood) machining. Dry machining considers machining with only compressed air to replace MWF, and in semi-dry machining beside compressed air some other components such as oil, water, $\mathrm{CO}_{2}$, liquid nitrogen etc. are used. There are no accepted classifications of MQL machining but literature and practice offer two levels of classification [5]. The first level includes the way in which aerosol is supplied into the machining zone (internal-through tool or external). Second level of classification includes the composition of the aerosol (simple: air-oil mixture or advanced: air-oil and some other components which enhance cooling and/or lubricating characteristic).

Studies showed that MQL machining with simple aerosol composition that includes only compressed air and oil has poor cooling capabilities and is not suitable for machining difficult-to-machine materials such as titanium and nickel based alloys where excessive heat generation is the main problem [6]. To increase cooling capability of the aerosol mixture, some other components such as: water, solid or gaseous $\mathrm{CO}_{2}$ are added to the aerosol [2].

Another way to increase cooling capability of MWF is to use liquefied gases such as: carbon dioxide, nitrogen and helium as a cooling medium. As this machining is performed at very low temperatures it is often referred to as cryogenic machining. Nitrogen and helium are not considered as pollutants. On the other hand carbon dioxide is air pollutant and unlike nitrogen and helium is heavier than air and could cause $\mathrm{CO}_{2}$ accumulation and oxygen deficiency problems on the shop floor [7]. Since carbon dioxide is gas without smell, its accumulation on the shop floor is very dangerous for machine tool operators.

Effectiveness of cryogenic machining in reducing tool wear, cutting force and surface quality of the work piece is already proven in experiments [8-11]. These experiments showed thatcryogenic machining is superior in comparison to MQL and dry machining. However, due to the high initial costs of cryogenic machining systems, application and development of MQL machining systems is in constant up rise. One of examples of MQL machining which performs similar as flood machining (or even better $[3,12]$ ) is advanced MQL machining with external supply of aerosol that includes compressed air, oil and water. The system supplies machining zone with water droplets covered with thin oil film. This semi-dry machining system is used in experimental research. In this experimental research, dry machining is performed without use of any metal working fluids.

Nickel-based super alloys are found in a wide range of applications. The most prominent use is in the manufacture of gas turbines for use in commercial and military aircraft, power generation, and marine propulsion [13]. Super alloys also find important applications in the oil and gas industry, space vehicles, submarines, nuclear reactors, military electric motors, chemical processing vessels, and heat exchanger tubing.

Application of nickel based super alloys depends upon their characteristics. Among the important characteristics high temperature creep resistance is one of most important properties. Creep takes place over time and results from long-term exposure to stress levels, and is more severe in materials subjected to heat for long periods. If the working temperatures are closer to the material melting point creep is even more intense. For example, a turbine blade made 
of a non-creep resistant material and used in a high temperature environment may creep over time, contact the housing and damage the blade. Component failure is often the result of creep. Another important property of super alloys is corrosion resistance. Corrosion resistance arises from the formation of a protective oxide layer which protects the underlying material.

Since their introduction, a wide range of nickel-based super alloys have been developed. However, two families of nickel-based super alloys stand out. The first family of nickel-based super alloys, developed in the 1940s for use in early jet engines is known as Nimonic family. These alloys typically consist of more than $50 \%$ nickel and $20 \%$ chromium. The second family of nickel-based super alloys is the Inconel alloys, which are made using nickel, chrome and some iron. These two families become synonyms for heat resistant high strength materials.

Nimonic 263 is typical representative of heat resistant nickel based super alloys used for machine parts that work on elevated temperatures. Nimonic alloy 263 is an age-hardenable nickel-cobalt-chrome-molybdenum alloy which was designed to have excellent fabrication characteristics in the annealed condition but also very good aged strength properties. Nimonic alloy 263 was developed to provide a sheet material which could be readily fabricated and would offer improved ductility in welded assemblies to replace NIMONIC alloy 80A. It is supplied in the annealed condition and its excellent ductility in this condition makes it suitable for cold forming as well as hot working. Alloy 263 can be welded using matching composition filler wire in both Tungsten Insert Gas (TIG) and Metal Insert Gas (MIG) forms. Regarding the composition of Nimonic alloys, they are regarded as difficult-to-machine materials [14]. These materials produce excessive heat during machining operations. Since nickel based alloys have low heat conductivity, heat produced during machining operations results in very high cutting temperatures. High cutting temperatures led to excessive tool wear and low surface quality. Concerning this, large quantity of coolant is recommended during machining operations.

To make this experimental research as environmentally friendly as possible, oil used in experiments was refined rapeseed oil. Besides that, experiments showed that bio-based oils exhibit better results than petroleum based oils $[15,16]$.

\section{Experimental work:-}

Experimental research was conducted in LORAM - Laboratory for Metal Cutting and Machine Tools of University of Zenica. Conventional lathe has been used. Experimental setup is shown in Figure 1. Three component dynamometer (Kistler Type-9265B) was used to measure cutting forces. Cutting temperature was measured by means of infrared camera Fluke Type-TI32 and surface roughness was measured with Perthometer M1. All three devices are shown in Figure 2.

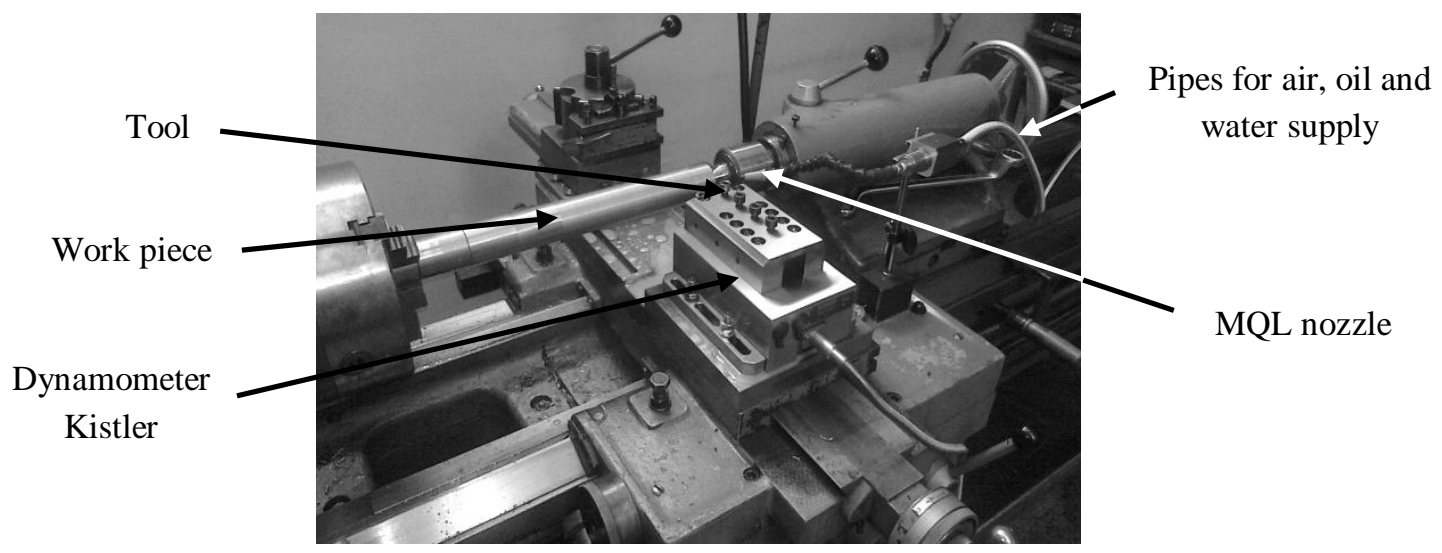

Figure 1:- Experimental setup 

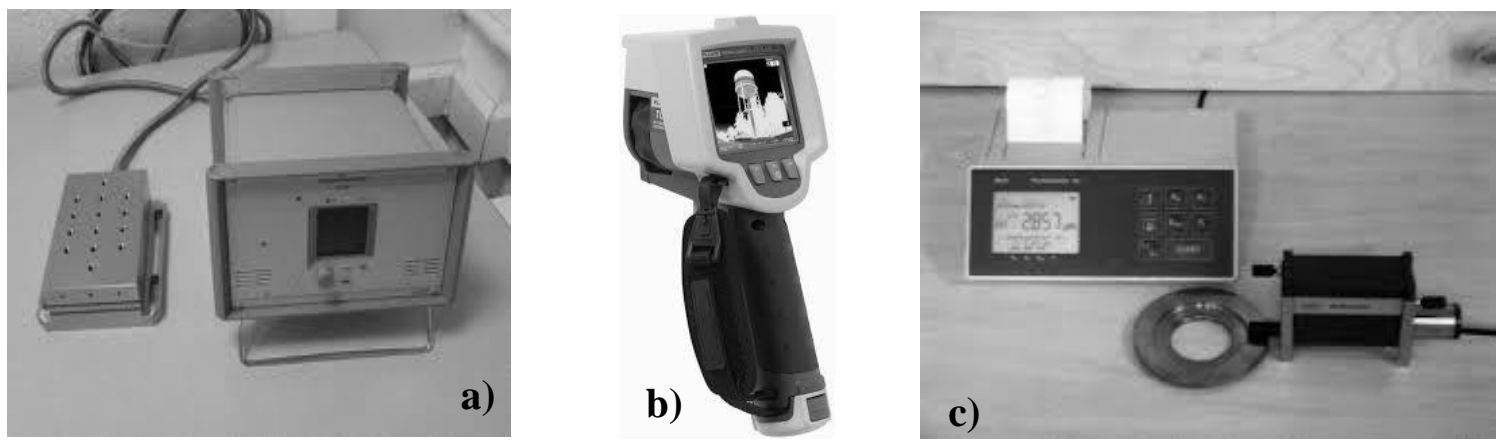

Figure 2:- Equipment for measurement of:

a) cutting forces, b) temperatures and c) surface roughness

Temperature measurements should be used with caution since using this apparatus only temperature of chip that is being removed could be measured (Figure 3(left)). Temperature of tool tip cannot be measured with this apparatus, because it is not visible during machining. It was assumed that temperature of the chip being removed is in direct proportion to cutting temperature.
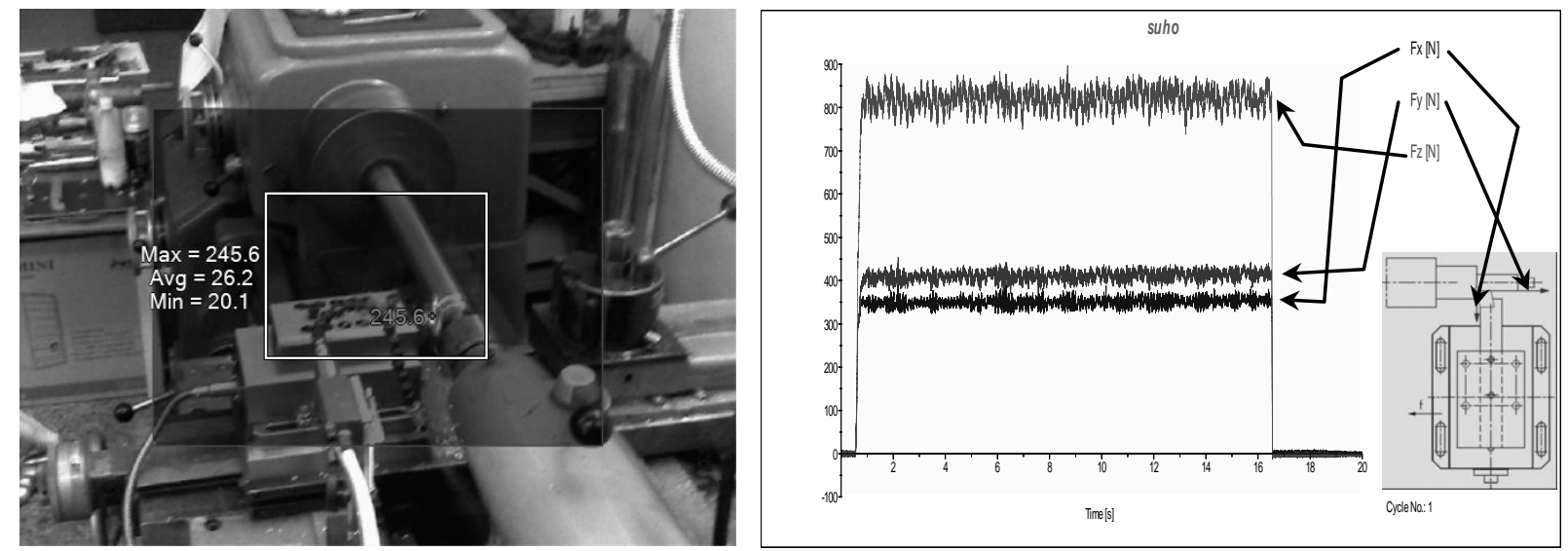

Figure 3:- Example of temperature measurement (left) and cutting forces measurement (right)

Semi-dry machining is performed using advanced MQL system type OoW (Oil-on-Water) produced by Daido Metal Co Japan. Main components of OoW system are presented in Figure 4. This MQL system makes droplets of water $100-200 \mu \mathrm{m}$ in diameter with oily film around it, as shown in Figures 5 and 6. Droplets captured on paper show that diameter of droplets is in the given range. Taking into account that diameter of droplets is larger after contact with hard surface, diameter of a flying droplet is closer to $100 \mu \mathrm{m}$. Comparing to MQL with only compressed air and oil used (size of the particles 5 to $30 \mu \mathrm{m}$ ) these particles are up to 20 times larger. Studies show that size of the particles could be essential for effectiveness of MQL machining. Reported effectiveness of this system $[2,12,17]$ indicates that size of OoW droplets could still be in acceptable range. 


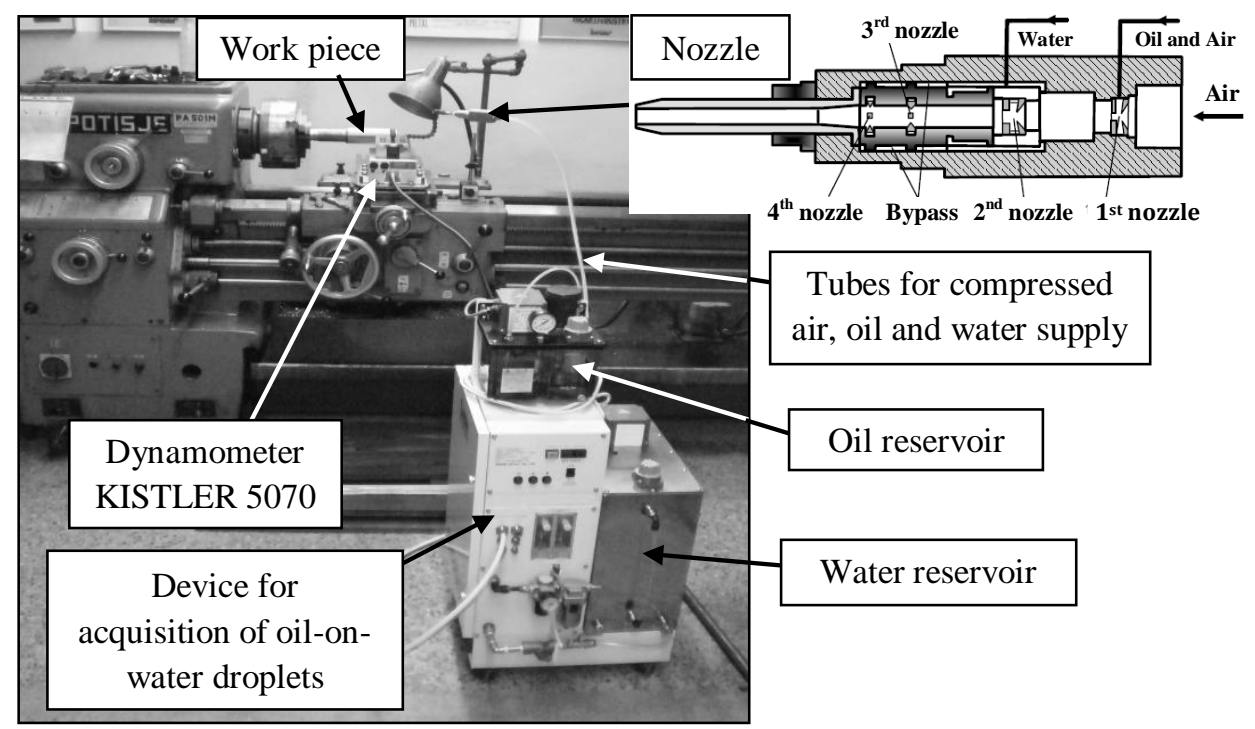

Figure 4:- Device for acquisition of Oil-On-Water droplets with detail of nozzle cross section

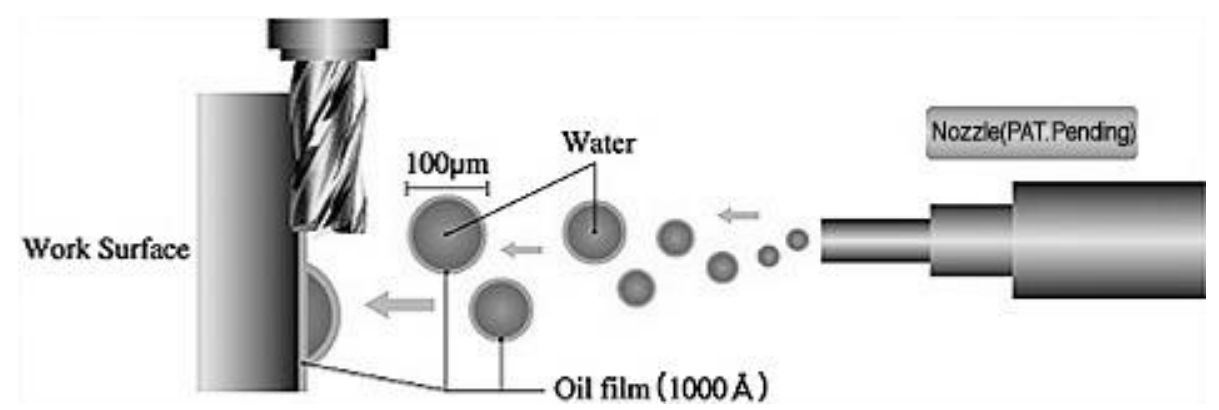

Figure 5:- Oil-On-Water droplets [17]

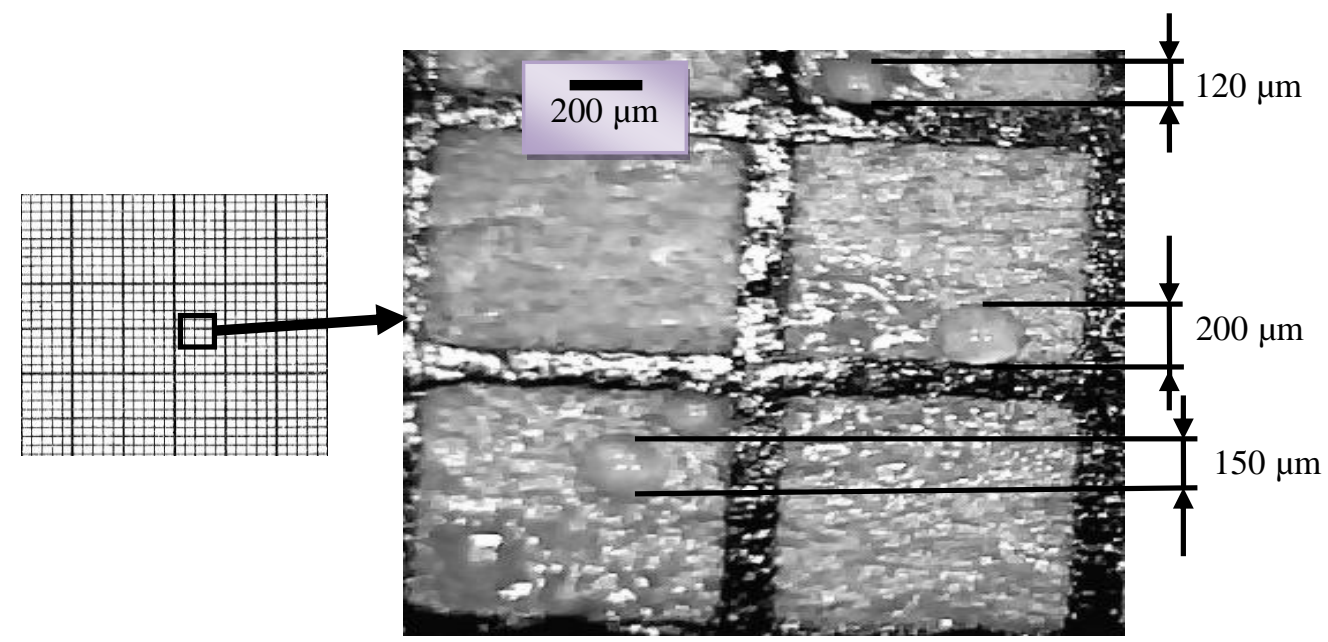

Figure 6:- Oil-On-Water droplets captured on paper with millimeter division 
MQL system settings are as follows: oil consumption is in range from 10-50 ml/h and water from 300 to $1800 \mathrm{ml} / \mathrm{h}$. The pressure of compressed air used for atomization of oil and water is $0.2 \mathrm{MPa}$.

Oil used in experiments is refined rapeseed oil with excellent lubrication properties. Rapeseed oil is probably the best natural lubrication media on the market but widely avoided because of residue oil that makes gummy and sticky stains on the machine and work piece, especially undesirable on finish surface of the work piece.

Work piece material is nickel based super alloy Nimonic 263 which is a typical representative of heat resistant alloys used in gas turbines. Chemical composition of Nimonic 263 is presented in Table 1, and its mechanical properties are shown in Figure 7. Two work pieces are selected. First one was in cast condition and second one was after casting forged with $60 \%$ deformation.

The aim of this research is to investigate difference between dry and semi-dry machining concerning cutting forces, cutting temperatures and surface roughness $R_{a}$ and to optimize the MQL parameters such as: quantity of oil, quantity of water and nozzle position in relation to cutting force, cutting temperature and surface roughness.

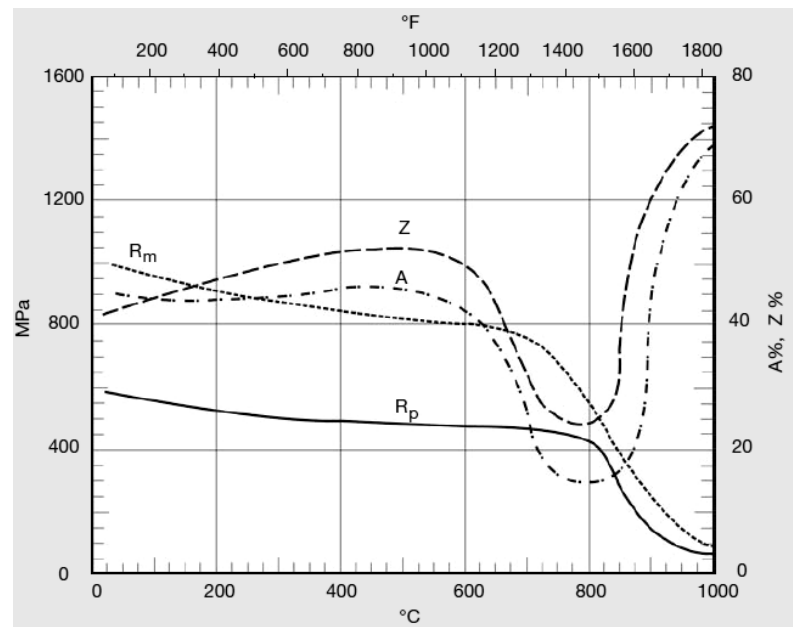

$A=$ Elongation

$R m=$ Tensile Strength

$R p=0.2 \%$ Proof Stress

$Z=$ Reduction of Area

Figure 7:- Tensile properties of bar. Heat treatment $2 \mathrm{~h} / 1150^{\circ} \mathrm{C} / \mathrm{WQ}+8 \mathrm{~h} / 800^{\circ} \mathrm{C} / \mathrm{AC}$

Table 1:- Chemical composition of Nimonic 263 and Nimocast 263

\begin{tabular}{|l|c|c|c|c|c|c|c|c|c|c|c|c|c|}
\hline \multirow{2}{*}{ Alloy } & \multicolumn{10}{|c|}{ Composition (\%) } \\
\cline { 2 - 15 } & $\mathrm{C}$ & $\mathrm{Si}$ & $\mathrm{Cu}$ & $\mathrm{Fe}$ & $\mathrm{Mn}$ & $\mathrm{Cr}$ & $\mathrm{Ti}$ & $\mathrm{Al}$ & $\mathrm{Co}$ & $\mathrm{Mo}$ & $\mathrm{B}$ & $\mathrm{Zr}$ & $\mathrm{Ni}$ \\
\hline Nimonic 263 & 0.04 & 0.04 & 0.2 & 0.7 & 0.2 & 19.0 & 1.9 & 0.3 & 19.0 & 5.6 & 0.001 & 0.02 & $\mathrm{Rest}$ \\
& 0.08 & $\mathrm{max}$ & $\max$ & $\max$ & 0.6 & 21.0 & 2.4 & 0.6 & 21.0 & 6.1 & $\max$ & $\max$ & \\
\hline Nimocast 263 & 0.06 & 0.04 & 0.2 & 0.7 & 0.6 & 20.0 & 2.3 & 0.5 & 20.0 & 6.0 & 0,001 & 0,02 & $\mathrm{Rest}$ \\
& & $\max$ & $\max$ & $\max$ & $\max$ & & & & & & $\max$ & $\max$ & \\
\hline
\end{tabular}

Two series of experiments are performed. In the first set of experiments, cutting speed, depth of cut and feed are varied and MQL parameters are held on constant level (quantity of water $250 \mathrm{ml} / \mathrm{h}$; quantity of oil $50 \mathrm{ml} / \mathrm{h}$; pressure of compressed air 0.2 MPa, nozzle position: rake side of the tool). This experiment was performed to check a level of cutting speed, feed, depth of cut and type of cutting tool to be used in second set of experiments which were conducted by varying MQL machining parameters. The second set of experiments was planned using full factorial experimental design and following, MQL parameters were varied: quantity of water, quantity of oil and nozzle position.

\section{Results and Discussion:-}

\section{Experimental setup No.1 - castings:-}

Settings for first series of experiments are shown in Table 2. Experiments were performed and cutting forces, temperatures and surface roughness were measured; data is presented in the Table 3. Graphical interpretation of results from Table 3 is shown in Figures 8, 9 and10. 
All experiments with first work piece are characterized by the intensive tool wear (Figure 11). It can be seen that wear occurs on rake face and flank face. Tool edge shown in Figure 11 is used in experiment number 5 on a machining length approximately $50 \mathrm{~mm}$.Same tool edge was used for MQL and dry machining. First $25 \mathrm{~mm}$ was for MQL machining and remaining $25 \mathrm{~mm}$ was for dry machining.

Table 2:- Experimental settings for the first work piece

\begin{tabular}{|l|l|l|}
\hline $\begin{array}{l}\text { OoW } \\
\text { (Oil on } \\
\text { Water) }\end{array}$ & Quantities & Oil: $50 \mathrm{ml} / \mathrm{h}$, Water: $250 \mathrm{ml} / \mathrm{h}$, Air $6000 \mathrm{Nl} / \mathrm{h}(100 \mathrm{Nl} / \mathrm{min})$ \\
\cline { 2 - 3 } & Particle size & $100-200 \mu \mathrm{m}$ \\
\hline Dry machining & Without use of MWFs \\
\hline Work piece material & Nimonic $263-$ casting \\
\hline Tool & $\begin{array}{l}\text { PVD coated cemented carbides with following designation: SNMG 120408- } \\
\text { SM and CNMG } 120408\end{array}$ \\
\hline Work piece material diameter & $\emptyset 60 \mathrm{~mm}$ \\
\hline Depth of cut & $0.25,0.5,1.0$ and $2.0 \mathrm{~mm}$ \\
\hline Feed & $0.04,0.1$ and $0.15 \mathrm{~mm} / \mathrm{rev}$. \\
\hline Cutting speed & 23,60 and $100 \mathrm{~m} / \mathrm{min}$ \\
\hline
\end{tabular}

Table 3:- Results of experiments with first work piece (settings according to Table 1.)

\begin{tabular}{|c|c|c|c|c|c|c|c|}
\hline \multirow{2}{*}{$\begin{array}{c}\text { Number of } \\
\text { experiment }\end{array}$} & \multirow{2}{*}{$\begin{array}{c}\text { Cutting } \\
\text { speed }\end{array}$} & \multirow{2}{*}{$\begin{array}{c}\text { Feed } \\
(\mathrm{mm} / \mathrm{mev})\end{array}$} & \multirow{2}{*}{$\begin{array}{c}\text { Depth } \\
\text { of cut } \\
\end{array}$} & & \multicolumn{2}{|c|}{ MQL machining } & \multicolumn{2}{c|}{ Dry machining } \\
\cline { 5 - 8 } & & & TemM & $\begin{array}{c}\text { FrezM } \\
(\mathrm{mm})\end{array}$ & $\begin{array}{c}{ }^{\circ} \mathrm{C} \\
\mathrm{N}\end{array}$ & $\begin{array}{c}\text { TemS } \\
{ }^{\circ} \mathrm{C}\end{array}$ & $\begin{array}{c}\text { FrezS } \\
\mathrm{N}\end{array}$ \\
\hline 1 & 23 & 0.098 & 1.0 & 128 & 628 & 201 & 855 \\
\hline 2 & 60 & 0.142 & 0.5 & 121 & 495 & 176 & 516 \\
\hline 3 & 60 & 0.098 & 1.0 & 124 & 722 & 183 & 767 \\
\hline 4 & 100 & 0.04 & 0.25 & 45 & 154 & 72 & 545 \\
\hline 5 & 60 & 0.04 & 2.0 & 37 & 712 & 43 & 719 \\
\hline 6 & 60 & 0.098 & 1.0 & 218 & 592 & 242 & 714 \\
\hline
\end{tabular}

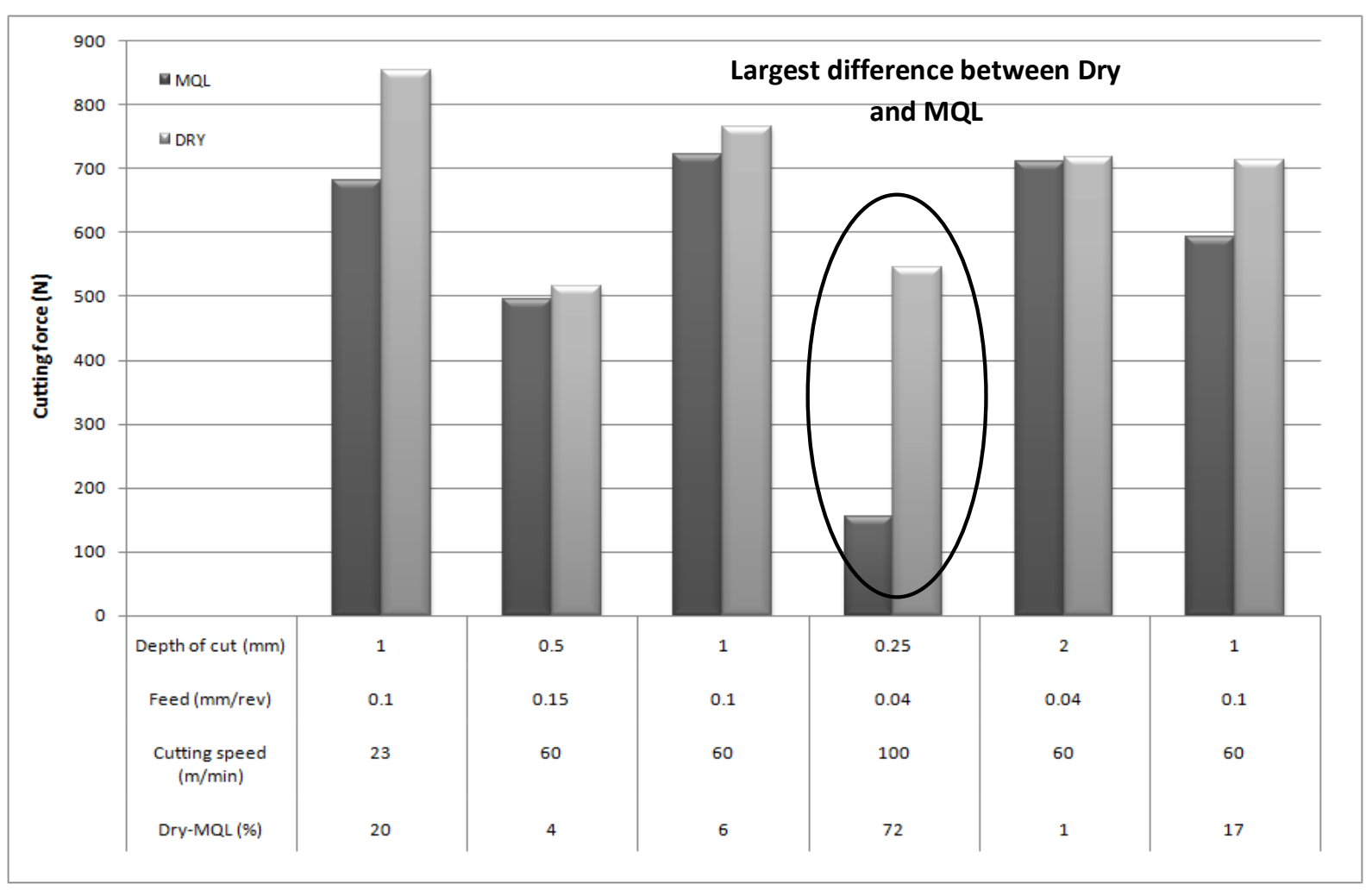

Figure 8:- Cutting force for experiments with first work piece (refer Table 3.) 


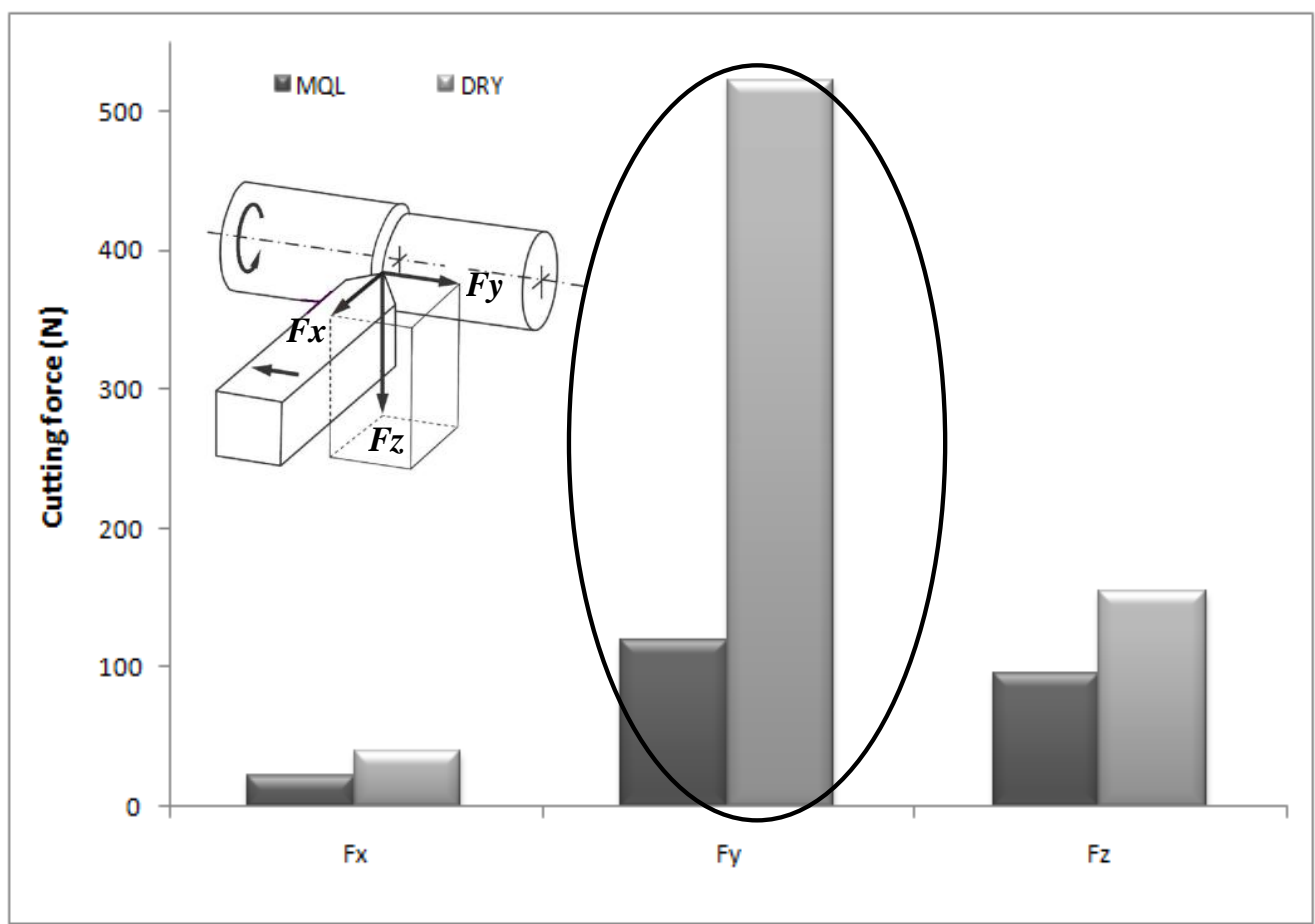

Figure 9:- Cutting force components for the experiment number 4 according to Table 3

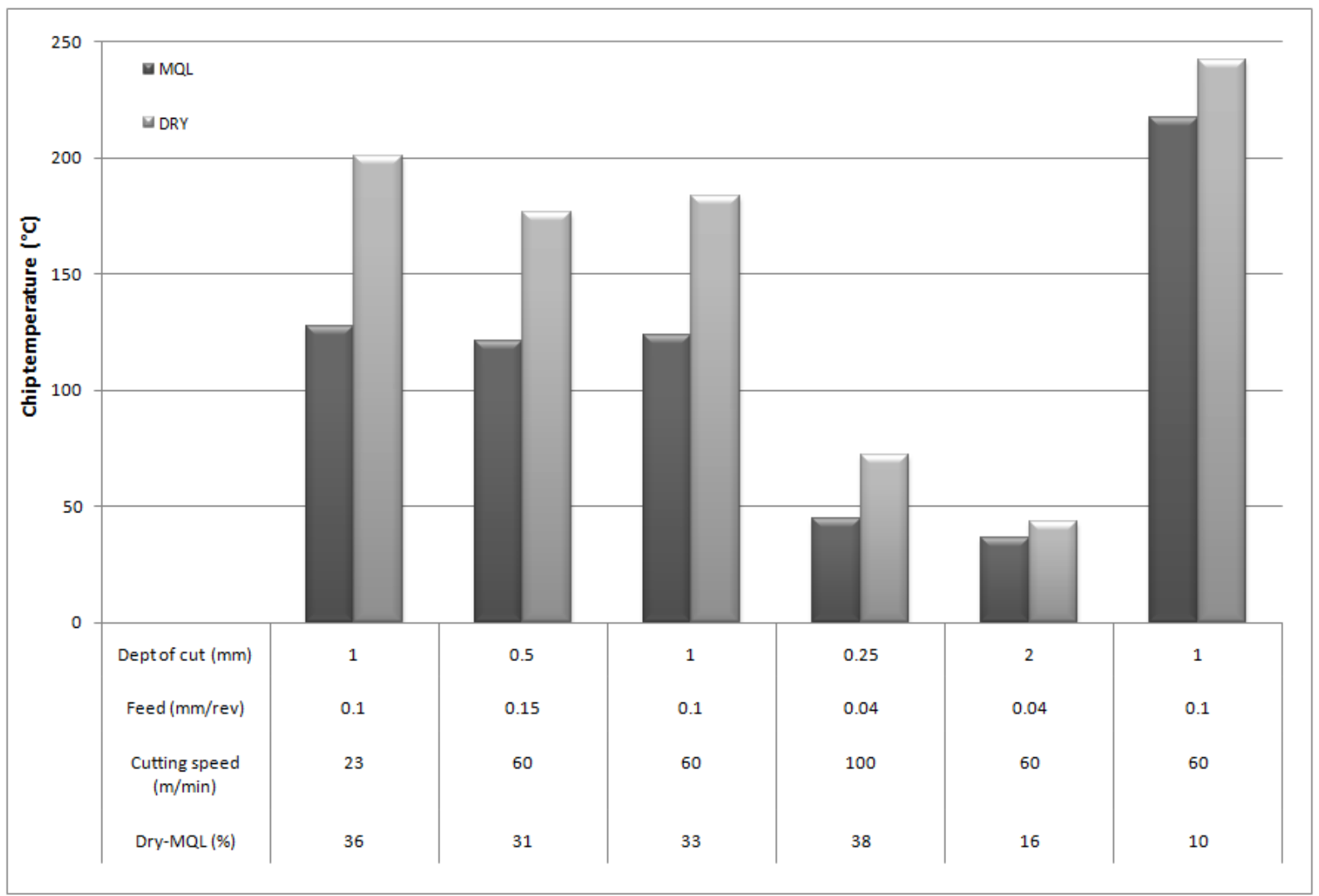

Figure 10:-Chip temperatures for experiments with first work piece (refer Table 3.) 


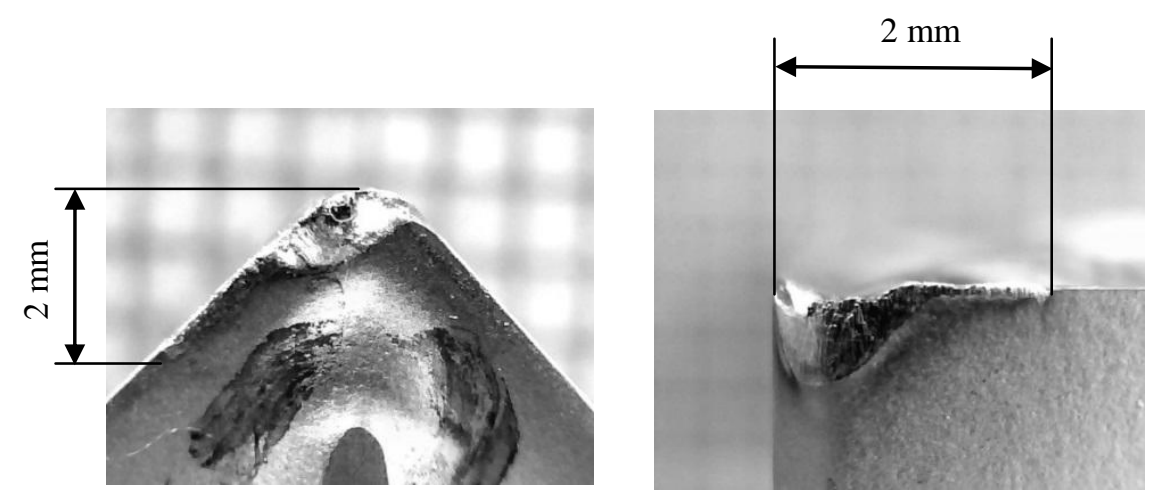

Figure 11:-Cutting tool SNMG 120408-SM rake face (left) flank face (right)

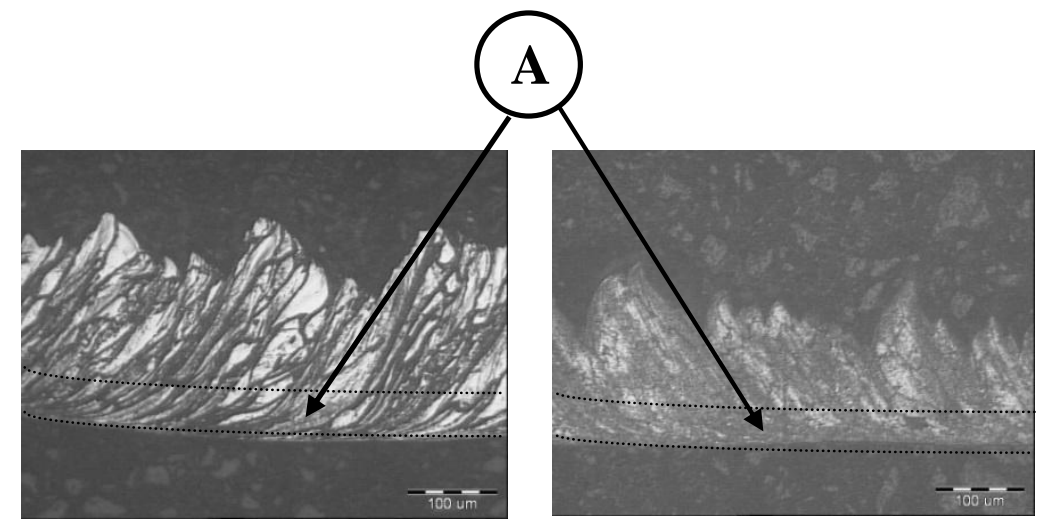

Figure 12:-Metallographic image of chip, MQL (left) and dry machining (right)

On the basis of generated experimental data for experimental setup No.1 presented in Tables 2 and 3, as well as Figures 8 to 12 the following conclusions were made:

- For the same depth of cut and feed, MQL machining gives $20 \%$ smaller cutting force when machining is performed at lower cutting speed of $23 \mathrm{~m} / \mathrm{min}$, Figure 8 . That means $20 \%$ less energy for cutting process is needed when using MQL, concerning proper power calculation from spindle to drive.

- The largest difference between cutting forces (MQL vs. dry machining) is at a cutting speed of $100 \mathrm{~m} / \mathrm{min}$ and at feed of $0.04 \mathrm{~mm} / \mathrm{rev}$, as shown in Figure 8 experiment number 4. Cutting force components for this experiment are shown in Figure 9. Analysis of cutting force components showed that, under given machining conditions, feed force component $F_{y}$ decreased significantly. This is the main reason of this large difference between MQL and dry machining.

- As it can be seen in the Figure 10, temperature of the chip is always smaller with MQL machining. Maximum difference between MQL and dry machining is $38 \%$ in experiment number 4 (cutting speed $100 \mathrm{~m} / \mathrm{min}$, feed $0.04 \mathrm{~mm} / \mathrm{rev}$ and depth of cut $0.25 \mathrm{~mm}$ ) in favor to MQL machining. It is difficult to define influence of cutting speed, feed and depth of cut on chip temperature. On the other hand, chip temperature measurement was performed in a nonconventional way using infrared camera. In this way only temperature of chip moving away from the cutting zone could be measured and not in any case temperature on tool tip.

- Intensive tool wear shown in Figure 11 clearly indicate that this material belongs in a group of hard-to-machine materials. Figure show that tool wear is happening on both rake face and flank face. Metallographic images shown in Figure 12 reveal obstruction of proper flow of material with the formation of additional friction layer in root of the chip (designated with A in Figure 12).

\section{Experimental setup No.2 - cast then forged with 60\% deformation:-}

Machining conditions for the experiment No. 2 were: cutting speed $v=60 \mathrm{~m} / \mathrm{min}$, depth of cut $d=1 \mathrm{mmand}$ feed $f=1.5$ $\mathrm{mm} / \mathrm{rev}$. Selection has been madeupon data from the experiment No.1. Selected tool for experiment No.2 is cemented carbide insert SNMG 120408. 
Settings for this experiment are shown in Table 4. This experiment is performed according to factorial experimental design. Factor levels and intervals of variations are given in Table 5. Following factors have been controlled: quantity of water $(\mathrm{ml} / \mathrm{h})$; quantity of oil $(\mathrm{ml} / \mathrm{h})$ and nozzle position (rake face of the tool and flank face of the tool). Cutting speed, depth of cut and feed were held on a constant level $v=60 \mathrm{~m} / \mathrm{min}, d=1 \mathrm{mmand} f=1.5 \mathrm{~mm} / \mathrm{rev}$.

Experiments were performed and cutting forces, temperatures and surface roughness were measured; data is presented in the Table 6. Graphical interpretation of results from Table 6 is shown in Figures 13, 14, and 15.

Table 4:- Experimental settings for second work piece.

\begin{tabular}{|l|l|l|}
\hline \multirow{2}{*}{$\begin{array}{l}\text { OoW } \\
\text { Wat on }\end{array}$} & Quantities & $\begin{array}{l}\text { Oil: } 10 \text { to } 50 \mathrm{ml} / \mathrm{h}, \text { Water: } 300 \text { to } 1700 \mathrm{ml} / \mathrm{h}, \text { Air } 6000 \mathrm{Nl} / \mathrm{h} \text { (100 Nl/min), } \\
\text { Nozzle position: Rake side and Flank side }\end{array}$ \\
\cline { 2 - 3 } & Particle size & $100-200 \mu \mathrm{m}$ \\
\hline Dry machining & Without use of MWFs \\
\hline Work piece material & Nimonic 263 - forgings with $60 \%$ deformation \\
\hline Tool & $\begin{array}{l}\text { PVD coated cemented carbide with following designation: SNMG 120408- } \\
\text { SM }\end{array}$ \\
\hline Work piece diameter & $\emptyset 46 \mathrm{~mm}$ \\
\hline Depth of cut & $0.25 \mathrm{~mm}$ \\
\hline Feed & $0.04 \mathrm{~mm} / \mathrm{rev}$ \\
\hline Cutting speed & $23 \mathrm{~m} / \mathrm{min}$ \\
\hline
\end{tabular}

Table 5:- Levels of factors and their intervals of variation

\begin{tabular}{|l|c|c|c|c|}
\hline \multirow{2}{*}{ Level } & \multirow{2}{*}{ Designation } & Water $(\mathrm{l} / \mathrm{h})$ & Oil $(\mathrm{ml} / \mathrm{h})$ & Nozzle position \\
\cline { 3 - 5 } & & $x_{1}$ & $x_{2}$ & $x_{3}$ \\
\hline Basic & 0 & 1.0 & 30 & - \\
\hline Interval of variation & $\Delta x_{i}$ & 0.7 & 20 & Rake \\
\hline Upper & +1 & 1.7 & 50 & Flank \\
\hline Lower & -1 & 0.3 & 10 & \\
\hline
\end{tabular}

Table 6:- Plan matrix with natural levels of factors for experiments with second work piece

\begin{tabular}{|c|c|c|c|c|c|c|}
\hline $\begin{array}{l}\text { Point of the } \\
\text { matrix }\end{array}$ & $\begin{array}{c}\text { Water } \\
(1 / h)\end{array}$ & $\begin{array}{c}\text { Oil } \\
(\mathrm{ml} / \mathrm{h})\end{array}$ & $\begin{array}{l}\text { Nozzle } \\
\text { position }\end{array}$ & $\begin{array}{c}\text { Force } \\
\mathrm{N}\end{array}$ & $\begin{array}{l}\mathrm{Ra} \\
\mu \mathrm{m}\end{array}$ & $\begin{array}{c}\text { Chip Temperature } \\
{ }^{\circ} \mathrm{C}\end{array}$ \\
\hline 1 & 1.7 & 50 & Flank & 673 & 2.72 & 183 \\
\hline 2 & 1.7 & 10 & Flank & 692 & 2.05 & 143 \\
\hline 3 & 0.3 & 50 & Flank & 685 & 1.97 & 229 \\
\hline 4 & 0.3 & 10 & Flank & 693 & 2.24 & 237 \\
\hline 5 & 0.3 & 10 & Rake & 699 & 2.86 & 185 \\
\hline 6 & 0.3 & 50 & Rake & 676 & 1.95 & 189 \\
\hline 7 & 1.7 & 50 & Rake & 680 & 2.43 & 122 \\
\hline 8 & 1.7 & 10 & Rake & 681 & 2.83 & 127 \\
\hline 9 & 1.0 & 30 & Flank & 670 & 2.45 & 161 \\
\hline 10 & 1.0 & 30 & Rake & 675 & 2.51 & 154 \\
\hline \multirow{3}{*}{\multicolumn{2}{|c|}{ Dry machining }} & \multicolumn{2}{|c|}{ Trial No. 1} & 649 & 2.05 & 273 \\
\hline & & \multicolumn{2}{|c|}{ Trial No. 2} & 729 & 1.84 & 257 \\
\hline & & \multicolumn{2}{|c|}{ Average } & 689 & 1.94 & 265 \\
\hline
\end{tabular}




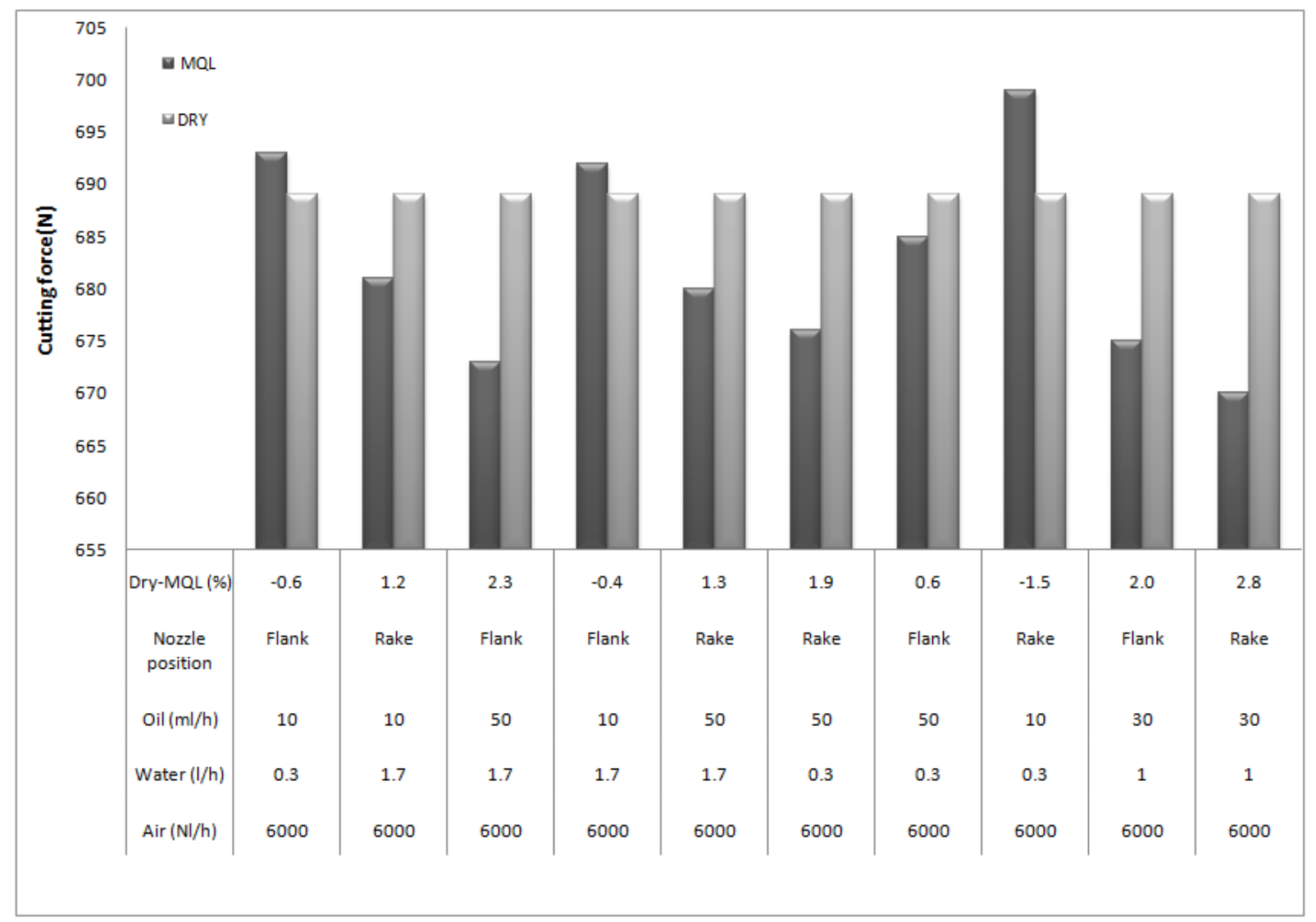

Figure 13:- Cutting force for experiments with second work piece (refer Table 6.)

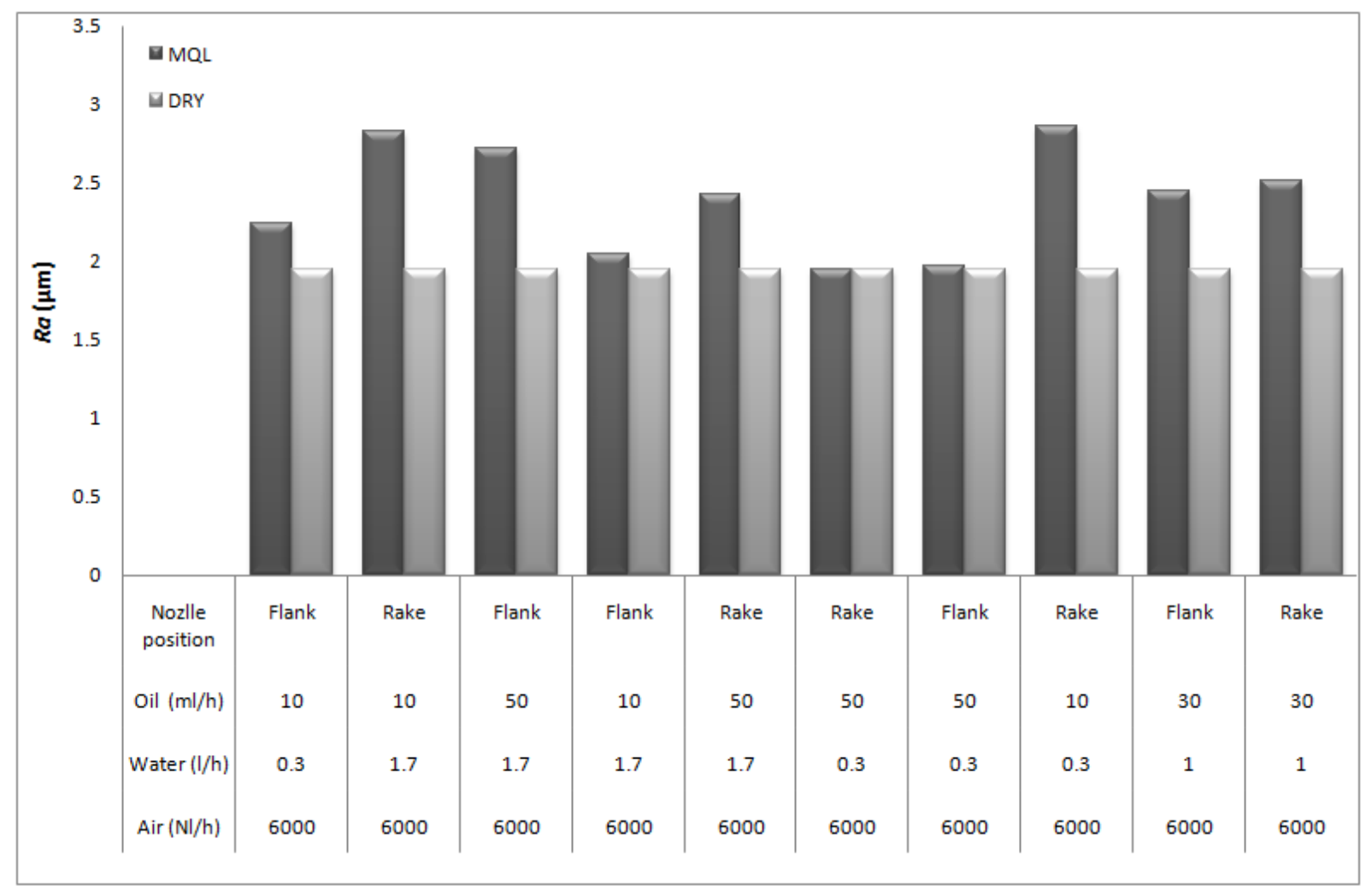

Figure 14:- Surface roughness $R_{a}$ for experiments with second work piece (refer Table 6.) 


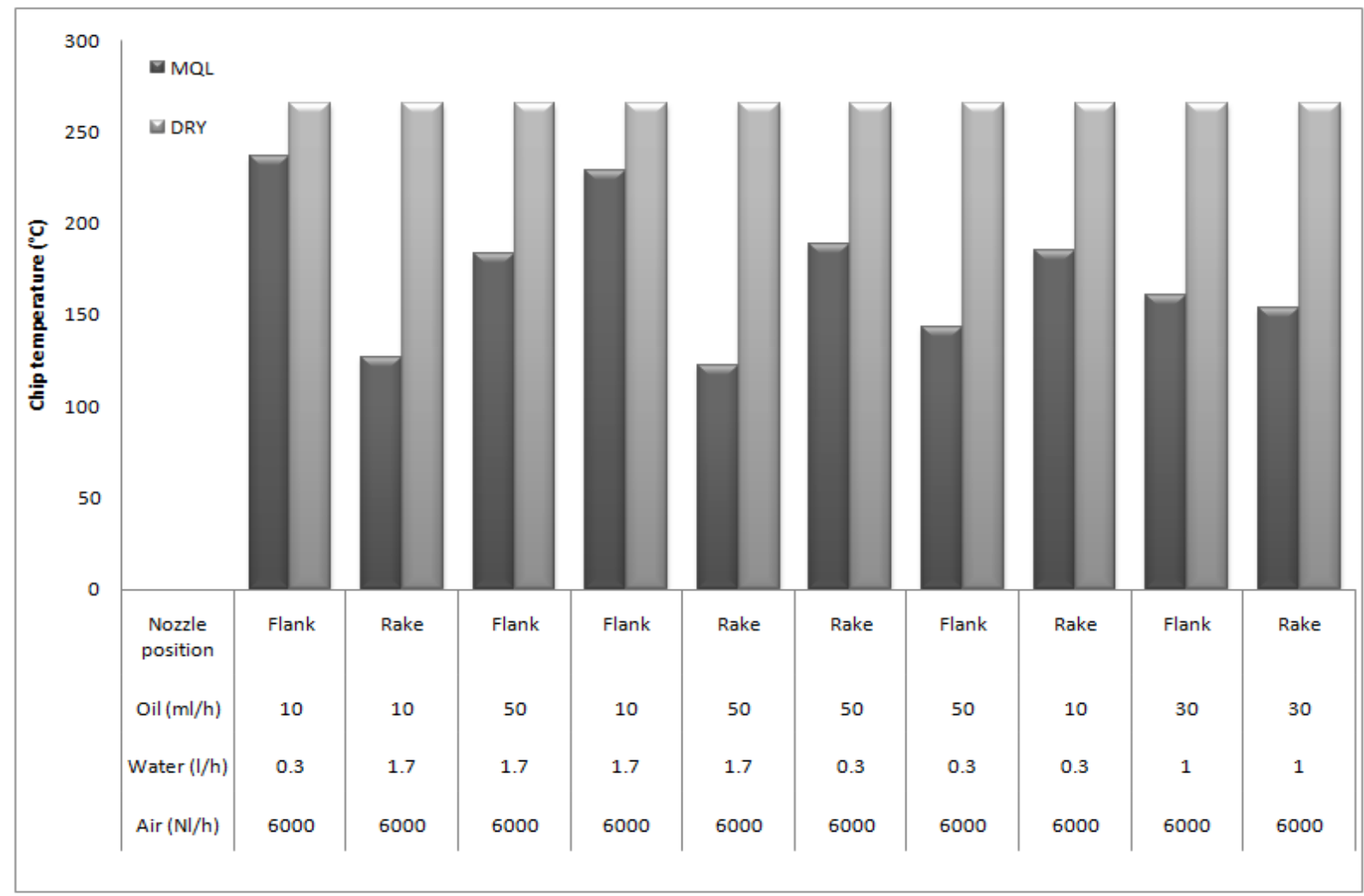

Figure 15:- Chiptemperature for experiments with second work piece (refer Table 6.)

The goal of these experiments is to investigate influence of three parameters of MQL system i.e.: quantity of water $(\mathrm{W}, \mathrm{ml} / \mathrm{h})$, quantity of oil $(\mathrm{O}, \mathrm{ml} / \mathrm{h})$ and nozzle position (NP, rake or flank face of the tool) on resultant cutting force $(F)$, surface roughness $(R a)$ and cutting temperature $(T)$. In that sense full factorial DOE with two repetitions at central point is used. Plan matrix with natural level of factors and results of experiments are shown in Table 6. Just for comparison, two trials with dry machining were performed; results are shown in Table 6, too. For the purpose of regression analysis, following designations are used:

W - Water, $\mathrm{ml} / \mathrm{h}$

$\mathbf{O}-\mathrm{Oil}, \mathrm{ml} / \mathrm{h}$

NP - Nozzle Position, Rake face or Flank face of the tool

WO - Water Oil

WNP - Water Nozzle Position

ONP - Oil Nozzle Position

WONP - Water Oil Nozzle Position

Regression analysis of experimental data from Table 6 gave the following regression models:

- $\quad$ Resultant cutting force $F$ :

$F=702.20-0.007 \mathbf{W}-0.41 \mathbf{O}+7.25 \mathbf{N P}+0.00009 \mathbf{W O}-0.009 \mathbf{W N P}-0.27 \mathbf{O N P}+$ +0.00029 WONP

- $\quad$ Surface roughness $R_{a}$ :

$R a=2.75-0.0002 \mathbf{W}-0.018 \mathbf{O}+0.34 \mathbf{N P}+0.00001 \mathbf{W O}+0.00009 \mathbf{W N P}-$ -0.006 ONP +0.000003 WONP 
- $\quad$ Cutting temperature $T$ :

$T=228.83-0.057 \mathbf{W}-0.154 \mathbf{O}-29.75 \mathbf{N P}+0.00034 \mathbf{W O}+0.0179 \mathbf{W N P}-$ -0.302 ONP + 0.0005 WONP

On the basis of experimental data and presented regression analysis, following conclusions were made:-

- Cutting forces are generally smaller with MQL machining, as shown in Figure 13. Exceptions are trials with minimal quantity of oil and minimal quantity of water when cutting forces are greater with MQL machining, regardless of nozzle position.

- Surface roughness $R_{a}$, shown in Figure 14 is mostly higher with MQL machining compared to dry machining without use of any MWFs. Exceptions are trials with maximum quantity of oil and minimum quantity of water when surface roughness $R_{a}$ is at same level,

- Chip temperature shown in Figure 15 is always smaller with MQL machining. Depending on combination of parameters, quantity of oil, quantity of water and nozzle position this difference can be up to $54 \%$ in the favor to MQL machining,

- Second order fitted line plots shown in Figure 16, 17 and 18 are used to find minimum cutting force, surface roughness and chip temperature.

Minimal cutting force is obtained for the following combination of parameters (Figure 16.):

Oil $=35.08 \mathrm{ml} / \mathrm{h}$, Water $=1100 \mathrm{ml} / \mathrm{h}$

As shown in Figure 17 regression equation for surface roughness has no local minimum. Minimal surface roughness $R_{a}$ is obtained when parameters are chosen left or right from local maximum i.e.:

Oil $=18 \mathrm{ml} / \mathrm{h}$, Water $=1166 \mathrm{ml} / \mathrm{h}$

Minimal chip temperature is obtained by the following combination of parameters (Figure 18.):

Oil $=28.05 \mathrm{ml} / \mathrm{h}$, Water $=1688.57 \mathrm{ml} / \mathrm{h}$

- Main effect plots for cutting force, surface roughness and chip temperature presented in Figure 19. show:

An increase of quantity of oil and water reduces cutting forces provided that increase of quantity of oil reduces cutting forces more quickly. Rake face position of nozzle gives smaller cutting forces compared to flank face position,

An increase of oil quantity reduces surface roughness $R_{a}$; on the other hand an increase of water quantity increases surface roughness $R_{a}$. Flank face position of nozzle gives smaller surface roughness $R_{a}$,

Naturally, increase of water quantity quickly decreases chip temperature. It is interesting that an increase of oil quantity slightly increases chip temperature. Rake position of nozzle gives smaller chip temperatures compared to a flank position of nozzle.

- From regression equations, it is obvious that nozzle position is the most influencing parameter on cutting force, surface roughness $R_{a}$ and chip temperature. Although, MQL machining gives better results concerning cutting force and chip temperature, that advantage for example for cutting force is only $2.8 \%$ maximum. 

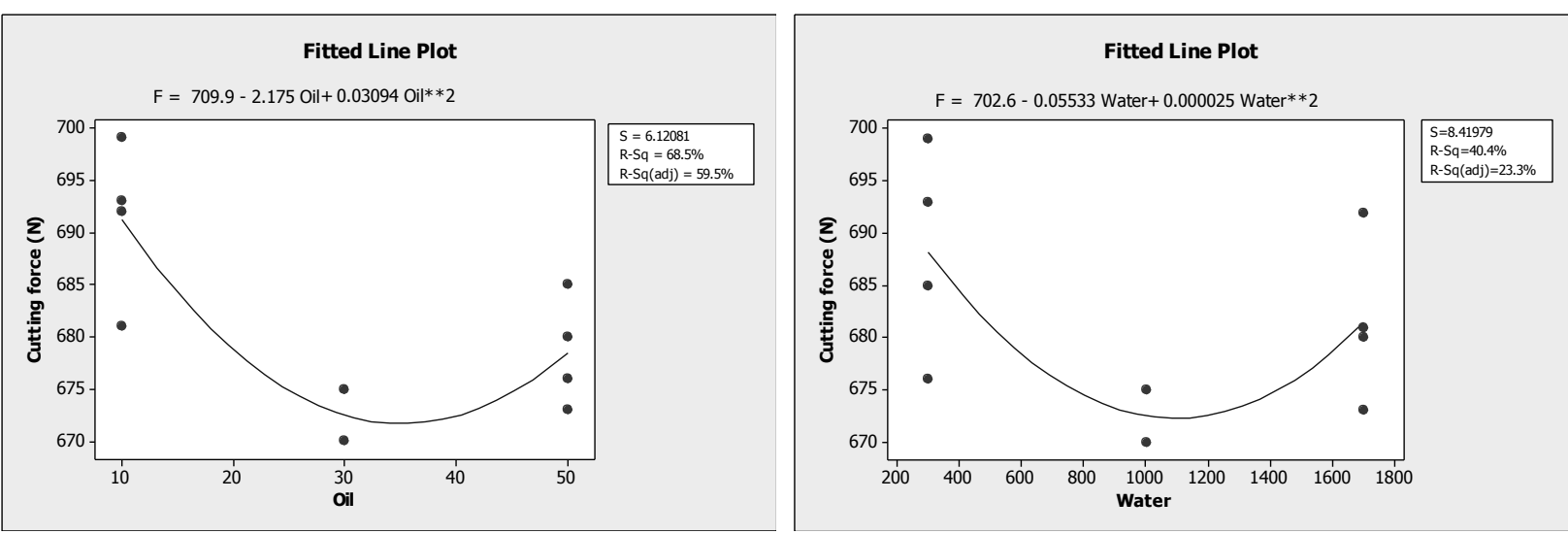

Figure 16.- Fitted line plot of the resultant cutting force versus quantity of oil (left) and quantity of water (right)
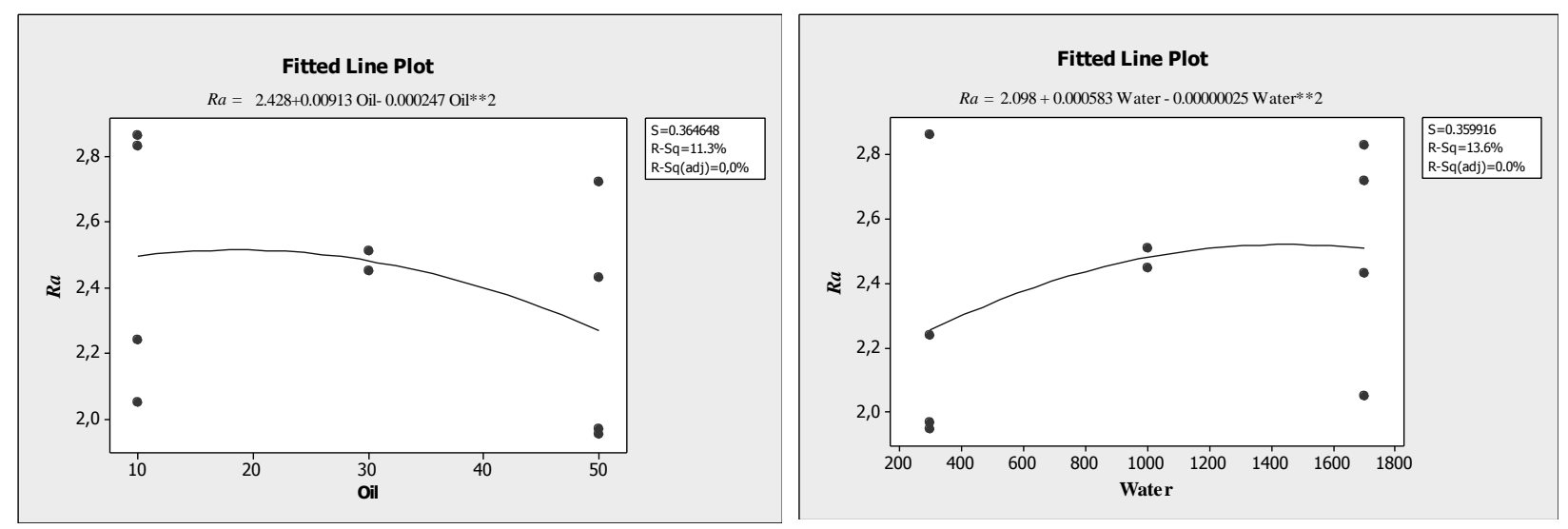

Figure 17:-Fitted line plot of the surface roughness $R_{a}$ versus quantity of oil (left) and quantity of water (right)
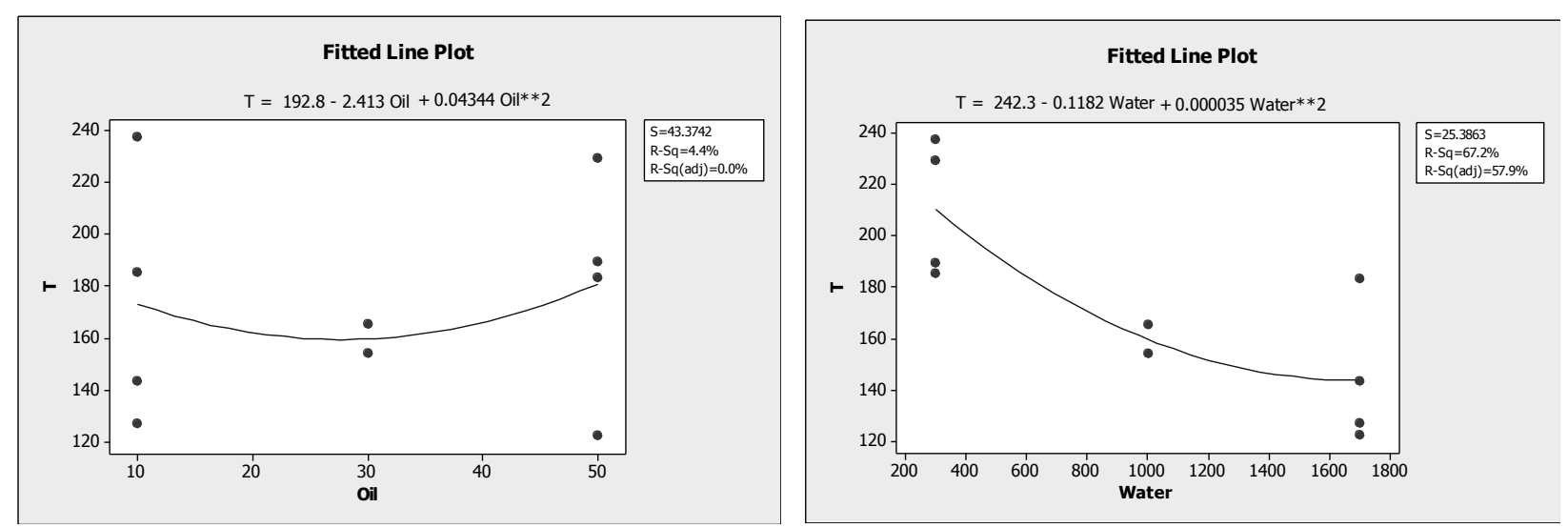

Figure 18:- Fitted line plot of the chip temperature versus quantity of oil (left) and quantity of water (right) 

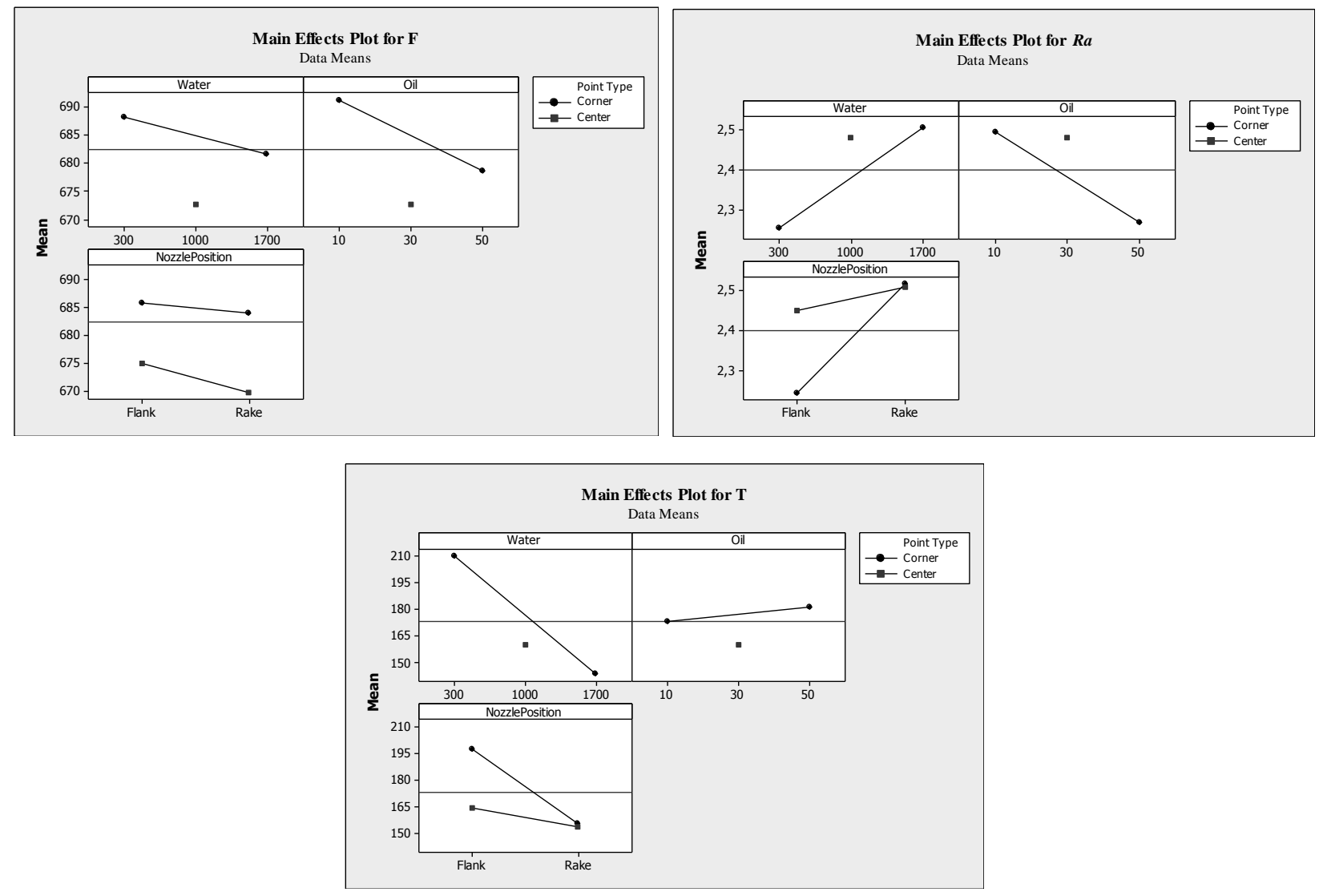

Figure 19:- Main effect plots

\section{Conclusion:-}

Machining of nickel based super alloy, especially NIMONIC 263, according to literature [14,18] even with intensive supply of MWFs to cutting zone, is a difficult process characterized by short tool life.

The economical application of MQL machining in this research is analyzed through lower cutting forces, better surface roughness and smaller chip temperature. Experiments are performed in order to find MQL machining conditions under which MQL machining gives results similar to flood machining. These experiments showed that recommended machining data from literature (cutting speed, feed and depth) and recommended tool geometry do not give expected results. According to [18] tool life of uncoated carbide has 20 to $30 \mathrm{~min}$ tool life, whereas coated carbide tool used in experiments with PVD coating designed for high temperatures resistant alloys has tool life less than $1 \mathrm{~min}$.

An experiment performed with cast specimen showed that cutting forces could be $20 \%$ smaller in comparison to the dry machining. That means that $20 \%$ less energy is needed when MQL is engaged. Chip temperature is $38 \%$ smaller with MQL. Intensive tool wear of both tools used in experiments points out that Nimonic 263 is hard-to-machine material. On the other hand, experiment with second specimen showed that application of advanced semi-dry machining technique (Oil-On-Water droplet) gives only 2.8\% decrease of cutting force. It is obvious that MQL application must be optimized not only through optimization of MQL parameters like quantity of oil, quantity of water and nozzle position but through cutting force, feed and depth of cut as well.

Regression models (1), (2) and (3) clearly indicated that nozzle position is most influenced factor on cutting force, surface roughness $R_{a}$ and chip temperature. But, in this research nozzle position parameter was of smallest attention and only two positions were chosen relatively to cutting zone (rake and flank). Future research of MQL machining should be performed with detailed definition of nozzle position like: angle of nozzle, distance from cutting zone, and pressure of compressed air used for atomization of oil and water. 
Cutting force are smaller with MQL machining and minimal cutting force for given variation of MQL parameters is achieved with water quantity $1100 \mathrm{ml} / \mathrm{h}$ and oil quantity $35.08 \mathrm{ml} / \mathrm{h}$.

Performed research shows that smallest surface roughness is achieved when aerosol mixture contains maximum quantity of oil and minimum quantity of water.

In comparison to dry machining cutting temperatures are significantly lower with MQL machining and that difference goes up to $54 \%$.

\section{References:-}

1. Oberg, E.,Jones, F.D.,Horton, H.L.\&Ryffel, H.H. (2004).Machinery's handbook (27th Edition) \& Guide to Machinery's Handbook, Industrial Press, pp.1143-1146.

2. Astakhov, V.P. (2004).Tribology of Metal Cutting, Elsevier, London.

3. Yoshimura, H., Itoigawa, F., Nakamura, T., \&Niwa, K. (2005). Development of nozzle system for oil-on-water droplet metalworking fluid and its application to practical production line, JSME International Journal, Series C 48(4): pp. 723-729.

4. Thakur, D.G., Ramamoorthy, B., \&Vijayaraghavan, L. (2009). Optimisation of Minimum Quantity Lubrication Parameters in High Speed Turning of super alloy Inconel 718 for Sustainable Development,World Academy of Science, Engineering and Technology 54, pp. 224-226.

5. Davim, J.P. (2008) Machining: Fundamentals and recent advances, Springer, London.

6. Su,Y., He, N.,Li, L.,Iqba,A., Xiao,M., Xu, S.\&Qiu, B. (2007). Refrigerated cooling air cutting of difficult-to-cut materials, International Journal of Machine Tools and Manufacture, 47, pp. 927-933.

7. Hong, S.Y. (1999).Economical and Ecological Cryogenic Machining, Journal of Manufacturing Science and Engineering, 123, pp. 331-338.

8. Outerio, J.C., Pina, J.C., M’Sauobi, R., Pusavec, F. \&Jawahir, I.S. (2008) Analysis of residual stresses induced by turning of difficult-to-machine materials, CIRP Annals - Manufacturing technology 57, pp. 77-80.

9. Pusavec, F., Hamadi, H., Kopac, J. \&Jawahir, I.S. (2011). Surface integrity in cryogenic machining of nickel-based alloy-Inconel 718, Journal of Materials Processing Technology, 4, pp. 773-783.

10. Yang, S., Puleo, D.A., Dillon, O.W.\&Jawahir, I.S. (2011). Surface layer modifications in Co-Cr-Mo biomedical Alloy from cryogenic burnishing, 1 st CIRP Conference on surface integrity (CSI), Procedia Engineering 19, pp. 383-388.

11. Kaynak, Y., Karaca, H.E., Noebe, R.D.\&Jawahir, I.S. (2013).Tool-wear analysis in cryogenic machining of Ni-Ti Shape memory alloys: A comparison of tool-wear performance with dry and MQL machining, Wear 306, pp. 51-63.

12. Itoigawa, F., Childs, T.H.C., Nakamura, T. \&Belluco, W. (2006). Effects and mechanisms in minimal quantity lubrication machining of an aluminiumalloy, Wear 260, pp. 339-344.

13. International Nickel Study Group (2013), Secretariat briefing paper No.20.

14. Betteridge, W.\&Heslop,J. (1974) The Nimonic alloys and other Nickel-Base High Temperature Alloys, Edward Arnold Limited - London.

15. Zhang, J. Z., Rao, P.N. \&Eckman, M. (2012).Experimental evaluation of bio-based cutting fluid using multiple machining characteristics, International journal of modern engineering, Volume 12, 2, pp. 35-44.

16. Safian, S., Hisyam, M.A. \&Aman, S. (2009). Evaluation of vegetable oil as alternative cutting lubricant when end milling martensitic stainless steel using uncoated carbide tool, Journal of advanced manufacturing and technology, 3 , 2. pp. 49-55.

17. Yoshimura, H., Itoigawa, F., Nakamura, T. \&Niwa, K. (2006). Study on stabilization of formation of oil film on water droplet cutting fluid. 2006, Trans. Jpn. Soc. Mech. Eng. C 72: 941-946.

18. Hračić, S., Optimizacijaobradestruganjemlegure Nimonic-C.263. (1988). Magistarski rad, MašinskifakultetUniverziteta „DžemalBijedič",Mostar. 